experiment kits, summer schools and printed materials.

The $B B C$ was paid $£ 1.47$ million for making programmes which amounted to more than 30 per cent of the fixed overhead expenditure of the university in 1971. At present the Open University programmes are prepared at Alexander Palace, but by 1976 the university hopes that the programmes which it needs will be made at a new audio visual complex to be built on the university campus at Bletchley. The Department of Education and Science has agreed in principle that the complex can be built-to be staffed and manned by the $\mathrm{BBC}$ - but at present the university and the DES are negotiating the money to be allocated. This, in the long run, will determine the number of studios to be built, but to build and equip a viable complex will cost about £4 million according to the Open University.

\section{SWINE DISEASE}

\section{Control of Swill Plants}

A Ministerial order to control the operations of pig swill plants is to be introduced shortly. Fears are growing that unless steps are taken soon the virus that is causing the current epidemic of swine vesicular disease may be recycled through pig swill.

The movement controls imposed last week on pigs throughout England and Wales should do much to limit the spread of the disease-more than 40 out of the 55 cases that have followed the original outbreaks have been attributable to stock movement-but at least five cases may be the result of contam-

\section{Lord Snow to the Fore}

SPEAKING at the Annual Dinner of the Institution of Electrical Engineers last week, Lord Snow described plans to shift the balance in universities towards the social sciences as "passing the confines of lunacy".

He went on to say that "we shall be spending thousands of pounds educating young people in social sciences and I cannot imagine any more foolish waste of money". $\mathrm{He}$ also bemoaned the fact that engineers in this country are for some reason less respected than in other countries.

Lord Snow said that far from being encouraged to study social sciences, many more undergraduates should be doing hard subjects like mathematics. They could acquaint themselves with social sciences at a later stage, he contended, as people had managed to do quite successfully in the past. inated swills and the original outbreaks were all on swill-fed farms.

Recycling can occur if a pig is slaughtered while it is incubating the disease (incubation takes 4 to 6 days). Those parts of the animal not used for human consumption go to plants which manufacture pig swill for use on more than 5,000 farms in England and Wales. If the meat from the slaughtered pig is not properly sterilized the virus will be carried over into the swill resulting in further infection.

This may not be the real problem, however. Swill plants are supervised by local authorities, and ministry officials are fairly happy that the meat is being sterilized. The problem chiefly lies in the organization of the plant. Sterilized swill may be recontaminated during the handling of raw swill, and it is this aspect of the operation that ministry officials want tightened up.

Swine vesicular disease is in itself not particularly serious. Infected pigs can recover. The problem is that the symptoms are identical to those of foot and mouth, and if swine vesicular disease was allowed to become endemic in Britain it could mask the much more serious foot and mouth disease. Foot and mouth can kill large numbers of cattle and pigs, and survivors give poor milk and meat yields. The only way to safeguard against this is to stamp out swine disease.

Not that that is proving easy. Although the amounts of virus excreted by infected animals are low compared to the amounts emitted by foot and mouth victims, the swine disease virus is remarkably persistent. There is no question of it being an unbeatable virus, but two of the three farms that were restocked recently have had fresh outbreaks. As a result restocking is not being attempted until eight weeks after disinfection of the farm is complete. Fortunately airborne transfer of the disease is unlikely as the animals excrete only small quantities of virus, and the chief cause of the fiftyfive secondary cases has been movement. Twenty herds contracted the disease at markets, five herds were infected by the transfer of infected pigs onto the same farm, and seventeen got the disease from infected lorries. Theoretically lorries are disinfected between each load of livestock, but clearly this is not being done or is not being done efficiently. Greater vigilance and the ban of stock movements should help. Of the remaining cases, one is due to local spread-by vermin or birds-five cannot be easily accounted for, and a further five may be the result of the virus being recycled in swill, although there is no positive evidence that this is so.

Contaminated swill may have been the cause of the original outbreaks. Poland, Austria, France and Italy all had outbreaks of the disease late last year. Austria almost certainly imported it from Poland. But Poland, France and Italy all import pork from the far east and it is possible that the disease came to Europe that way. Britain too imports pork, although not directly from the east, and it is possible that contaminated carcasses were imported, and their offal used as swill on the five farms were the primary outbreaks occurred.

But whatever the cause, the disease still has to be controlled. The movement ban and swiil controls should solve the problem in time, but the persistence of the virus could mean that it will be quite a long time. To date more than 27,000 pigs have been slaughtered, but slaughter seems the only policy. Developing a vaccine to combat the disease would take time, and the rapid turn round on pig farms (the average life of a pig in Britain is a little over five months) would make administering it an almost impossible task.

\section{ISAAC NEWTON TELESCOPE}

\section{To Move or Nof to Move}

THE row over the wisdom, or otherwise, of siting the 98-inch Isaac Newton telescope above the Pevensey marshes of Sussex has surfaced at last in the correspondence columns of The Times. Many astronomers have been unhappy about the location for years, and criticism has reached a high pitch since the inauguration of the telescope five years ago, but for the most part astronomers have succeeded in keeping the debate to themselves. This self-imposed embargo has now been breached by $\mathrm{Mr}$ W. Bates of Cheltenham, who wrote to The Times in response to an article by their science correspondent reporting the view of the Director of the Royal Greenwich Observatory, Dr Margaret Burbidge, that the telescope cannot be properly used at its present site, and that ultimately it will have to be moved. "Who," Mr Bates asked, "was responsible for this disgraceful waste of public money? What action is being taken against them?" (The Times, January 31,1973 .)

So far Mr Bates has not had his answer. But Mr P. Lancaster Brown of Beaconsfield, who has written several articles about the telescope, including one commissioned by the Central Office of Information, wrote to give some facts about the history of the telescope (The Times, February 5, 1973). The telescope was first suggested by Professor H. H. Plaskett in 1946 during his presidential address to the Royal Astronomical Society, and the original design was a Schmidt with an aperture 